\title{
INCIPIENT SYMMETRICAL PERIPHERAL GANGRENE COMPLICATING PNEUMONIA
}

\author{
BY \\ OLE STORSTEIN \\ From the Medical Department of the University Hospital, Bergen, and from the Department \\ of Pathology, University of Bergen, Norway
}

\begin{abstract}
Abrahams (1948) reported a case of incipient symmetrical peripheral gangrene complicating paroxysmal tachycardia. Swan and Henderson (1951) reported two cases of the same condition in myocardial infarction. It may therefore be worth while giving an account of another case of symmetrical peripheral gangrene, apparently provoked by pneumonia. The analytical studies of the gases of the arterial blood and the post-mortem examination may throw some light of the pathogenesis of this condition.
\end{abstract}

\section{Case Report}

S. O., a 58-year-old shop-assistant, was healthy until about October 20, 1948, three weeks before admission, when she started to become breathless. She had to stop and rest repeatedly on her way home after the days work. A couple of days later her fingers began to swell, especially in the morning, the swelling diminishing a little during the day. After a week the fingertips started to get blue, and at the same time the fingers became painful. The pains were constant and resembled tooth-ache, becoming worse while she was at work, packing and delivering cakes and pastries. After some days she therefore had to stop work. She consulted a physician, who gave her something to relieve the pain. At night she slept with her arms above her head, as this position relieved the pain somewhat. Her dyspnœa continued, but she had no pain in her chest and no cough.

On admission to hospital on November 13,1948 , the patient was very obese, her height being $153 \mathrm{~cm}$. and her weight $83 \mathrm{~kg}$. She sat in bed, and was very dyspnœic, with pronounced cyanosis, her cheeks, lips, chest, and back being dark blue in colour. The cyanosis was most pronounced at the fingertips, which were approximately the colour of blue-berries. The fingers were cold and very sensitive to the slightest touch. Her blood pressure was $145 / 60$; the temperature was $39.8^{\circ} \mathrm{C}$. and had been $39.7^{\circ}$, two days before admission when it was first taken; the pulse was 120 , regular; respiration rate was 40 . There was no œdema. Clinically the heart was enlarged to the left, the point of maximum impulse being $11.5 \mathrm{~cm}$. from the mid-line. At the apex a systolic murmur, grade 2, was heard. At the base of the right lung there was dullness to percussion and reduced breath sounds. At both bases there were numerous dry râles. The electrocardiogram was normal with left axis deviation. Chest X-ray then and a week later showed patchy infiltration in both lower lung fields, partly confluent. The examination of the eye-grounds showed shifting calibre of the arteries, arteriovenous nicking, and in the left eye-ground a small area of degeneration.

Measurement of the skin temperature on November 18 gave the following temperatures (room temperature $20^{\circ} \mathrm{C}$.): in the palm of the right hand $37.4^{\circ} \mathrm{C}$.; on the volar side of the mid-phalanges $36^{\circ} \mathrm{C}$.; at the end phalanges: 1 st finger, $32.8^{\circ} \mathrm{C}$.; 2 nd finger, $29.7^{\circ} \mathrm{C}$.; 3rd finger $35.5^{\circ} \mathrm{C}$. (this finger was not cyanotic); 4 th finger $32 \cdot 2^{\circ} \mathrm{C}$; ; and 5th finger $34^{\circ} \mathrm{C}$. On the left hand the temperature at the cyanotic end-phalanges of the $3 \mathrm{rd}, 4$ th and 5 th fingers were respectively: $28 \cdot 2^{\circ} \mathrm{C}$., $28 \cdot 2^{\circ} \mathrm{C}$. and $29^{\circ} \mathrm{C}$. 
There was some leucocytosis, the highest count of white blood corpuscles being 16,000 . Sedimentation rate was $35-68 \mathrm{~mm}$. an hour. There was a pronounced hypoproteinæmia: total protein $3.5 \mathrm{~g}$., albumin $2 \cdot 2$, globulin $1.3 \mathrm{~g}$. per $100 \mathrm{ml}$. The cold agglutination test was negative. Repeated blood-cultures were sterile.

On November 13 the arterial oxygen saturation was found to be 48.9 per cent (oxygen capacity $17 \cdot 1$, oxygen content $8 \cdot 4$ volumes per cent). The patient was treated continuously with oxygen (oro-nasal mask). On November 15 the arterial oxygen saturation was 68.8 per cent in the brachial artery and 69.3 per cent in the femoral artery half an hour after removal of the oxygen mask. Ten minutes after reapplication of the mask the arterial oxygen was fully saturated.

Apart from the oxygen treatment the patient was given sulphadiazine $16 \mathrm{~g}$. and penicillin 1.6 million O.U. The temperature fell slightly, to $38^{\circ} \mathrm{C}$., but the patient's general condition had deteriorated, and she died November 24.

Necropsy (Professor Waaler). There was cyanosis of the fingertips of the right hand with incipient gangrene of the 2 nd finger. On the left hand there was cyanosis of the $3 \mathrm{rd}$, 4th and 5th fingers, with incipient gangrene of the $3 \mathrm{rd}$.

The lungs were heavy and consolidated in all the lobes, the weight of the right lung being $980 \mathrm{~g}$. and of the left lung $780 \mathrm{~g}$. The hilar lymph nodes were hyperæmic and almost the size of walnuts. The heart weighed $400 \mathrm{~g}$. and showed no hypertrophy of the right ventricle. The spleen weighed $175 \mathrm{~g}$. and was soft.

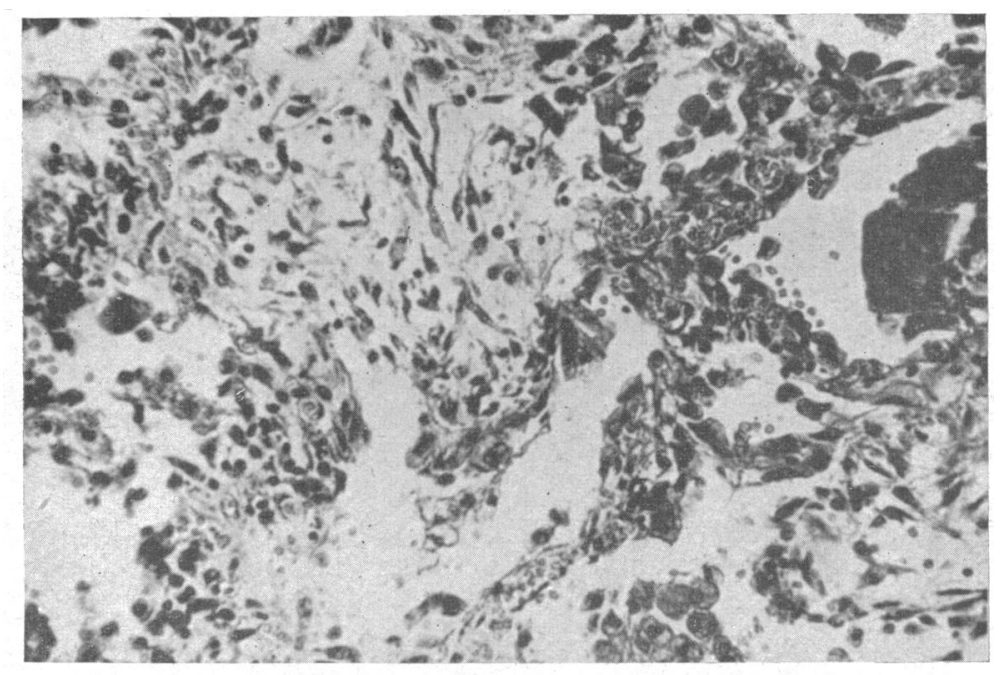

FIG. 1.-Pneumonia in organization; macrophages in the alveoli, proliferation of fibroblasts and blood vessels.

At the microscopic examination of the lungs the alveoli were filled with an exudate of macrophages, some granulocytes and degenerated red blood cells. The alveoli were partly atelectatic. In several places there was abundant proliferation of fibroblasts and blood vessels into the exudate (Fig. 1). In the right upper lobe a thrombus showing incipient organization was found in a small lung vein (Fig. 2).

The artery of the left 3rd finger was slightly thickened, with infiltration of lymphocytes and plasma cells in the adventitia, and moderate cell infiltration in the media. The lumen contained a thrombus in which the structure of the red cells had not quite disintegrated, with incipient organization (Fig. 3). 


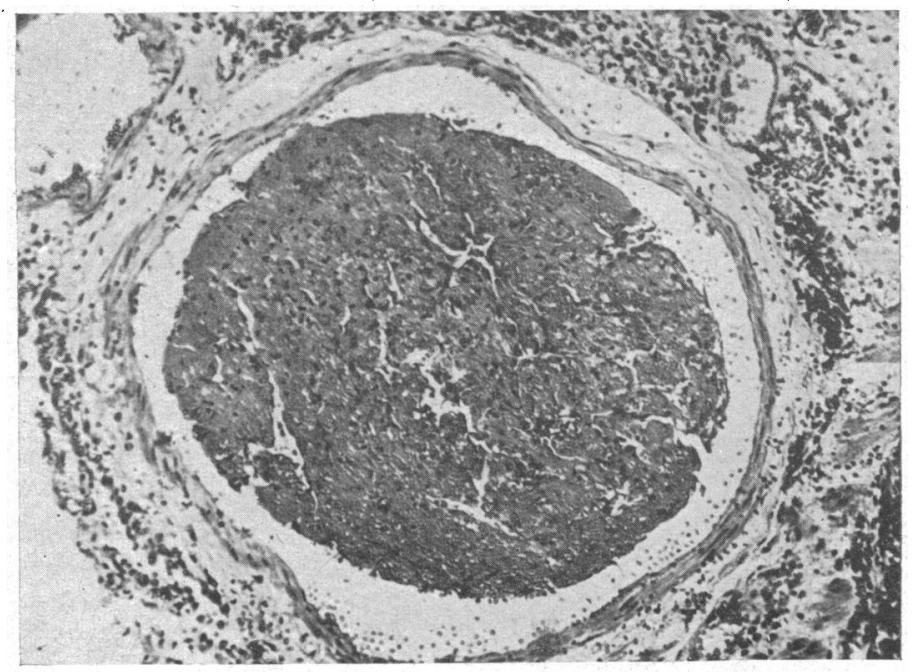

FIG. 2.-Unattached thrombosis in a small lung vein. Destruction of red blood corpuscles, incipient organization.

Frg. 3.-Thrombosis in a finger artery. Thickening of the artery wall with infiltrating cells in the adventitia and media; incipient organization of the thrombus.

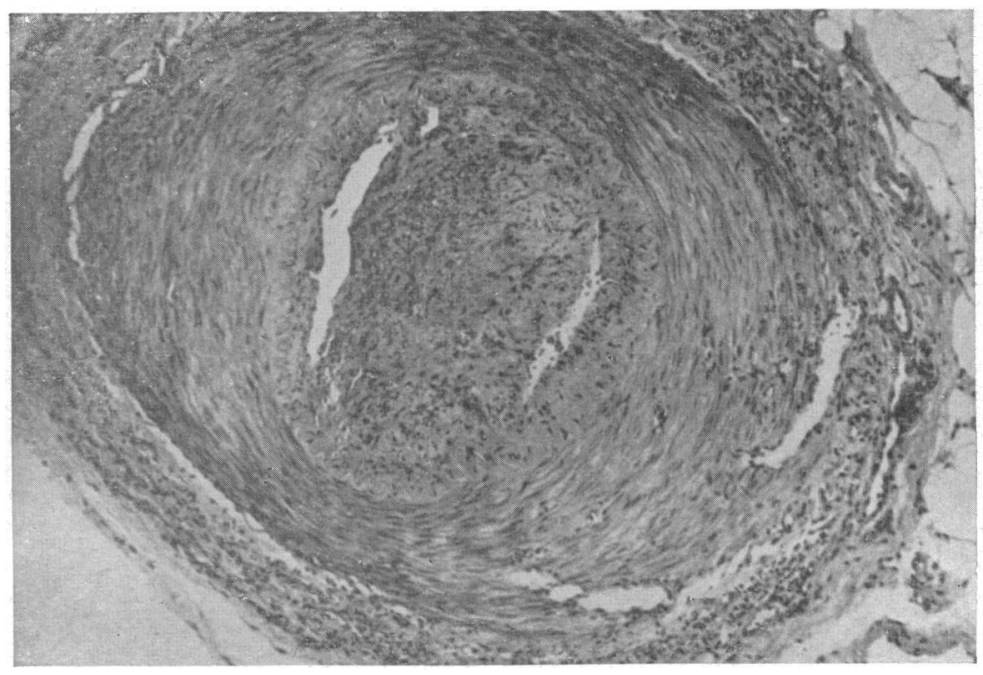

\section{Discussion}

The first point we wish to emphasize is the dyspnœa, which may have been caused by a migrating pneumonia. The stage of development of the pneumonia as revealed by necropsy would tally with the duration of the illness. The evoking agent of the pneumonia was not found, but bacteriological examination of the lungs at necropsy revealed coli bacilli and alpha-hemolytic staphylococci. The evoking agent may have been destroyed by the penicillin therapy or it may have been a virus.

The next point we wish to discuss is the symmetrical peripheral gangrene. The mechanism of this condition has been discussed by various authors, and there are three main possibilities.

Thrombo-embolism. Uhr (1938) has found septic arterial thrombi in gangrene during septicæmia, pneumococci in an artery in a gangrenous toe in a 9-year-old boy with pneumonia. Chatterjee (1940), too, mentions the possibility of the wandering of emboli from the diseased lung to the extremities. The finding in our case of a thrombus in a lung vein may lend support to this view. 
Vasospasm, possibly provoking thrombosis. Abrahams as well as Swan and Henderson, following Fishberg (1940), concludes that reflex peripheral vasospasm, evoked by a critical low cardiac output, was responsible in the cases they reported. Chatterjee came to the same conclusion in a case of gangrene of all four extremities in severe pneumonia. This view may also be supported by the finding by Perry and Davie (1939), of symmetrical peripheral gangrene of the lower limbs in congestive hypertensive heart failure.

In some of these cases there is presumably a low cardiac output, but certainly not in all. We did not measure the cardiac output in our case, but in anoxæmia there is usually a high cardiac output (Wiggers, 1949). A very short circulation time in this patient -8 seconds for the first taste to decholin, 17 seconds for the last taste-may indicate a high cardiac output.

Anoxamia. This point, has not, so far as we know, been discussed in the pathogenesis of this condition, nor has the arterial oxygen saturation been determined in any of the published cases. In cats, v. Euler and Liljestrand (1946) have shown that anoxæmia is a vasoconstricting factor in the lungs. The same reaction of the pulmonary circulation to anoxæmia is found in man (Motley et al., 1947). In the systemic circulation Wiggers supposes local vasoconstriction in some areas to maintain a normal blood pressure in vital organs like the kidney, brain, and coronary circulation. During continued severe anoxæmia this regulation of the systemic blood pressure by local vasoconstriction finally fails, and the blood pressure drops suddenly (Ershler et al., 1943).

In our patient the blood pressure was well maintained until death. It may well be, although we have no proof of it, that local vasoconstriction in the finger arteries, induced by severe anoxæmia, was the initiating factor in the thrombosing process. She was treated continuously with oxygen through an oro-nasal mask, apart from feeding and mouth toilette, for 13 days in all. It may be of interest to note that at necropsy there was no sign of oxygen poisoning (Barach, 1948; Ohlsson, 1947).

\section{Summary}

A case of incipient symmetrical peripheral gangrene of the fingers in a case of pneumonia is described. The necropsy revealed that the patient had probably had a migrating pneumonia and that thrombosis in a finger artery had caused the incipient gangrene. Three possible pathogenetic factors in this thrombosis are discussed: (1) embolic spread from the pneumonic lung, (2) vasospasm leading to thrombosis of the artery, and (3) anoxæmia causing vasoconstriction and thrombosis.

\section{REFERENCES}

Abrahams, D. G. (1948). Brit. H̀eart J., 10, 191.

Barach, A. L. (1948). Physiologic. Therapy in Respiratory Diseases. Philadelphia.

Chatterjee, S. C. (1940). Calcutta med. J., 37, 221.

Ershler, I., Kossmann, C. E., and White, M. S. (1943). Amer. J. Physiol., 138, 593.

V. Euler, U. S., and Liljestrand, G. (1946). Acta Physiol. Scand., 12, 301.

Fishberg, A. M. (1940). Heart Failure. Philadelphia.

Motley, H. L., Cournand, A., Werkø, L., Himmelstein, A., and Dresdale, D. (1947). Amer. J. Physiol., 150, 315.

Ohlsson, W. T. L. (1947). Acta Med. Scand. Suppl., 190.

Perry, C. B., and Davie, T. B. (1939). Brit. med.J., 1, 15.

Swan, W. G. A., and Henderson, C. B. (1951). Brit. Heart J., 13, 68.

Uhr, J. S. (1938). Amer. J. Dis. Children, 56, 1317.

Wiggers, C. J. (1949). Physiology in Health and Disease. Philadelphia. 